\title{
Retrospective mapping of the XVI century Samtskhe-Javakheti viticulture and fruit farming
}

\begin{abstract}
The presented work deals with the spread of viticulture and fruit farming in the Middle Ages in the Samtskhe-Javakheti region in Georgia. The current state of the farming sectors mentioned and those pivotal moments in Georgian history that had an influence on agriculture are also considered in the article. The changes that determined the viticulture geography from the second part of the 16th century up to the present day are also discussed. The study is mainly based on the census document created in 1574. The article represents the geographic distribution patterns of vineyards and orchards, as well as wine production capacity and the fruit harvest. Retrospective mapping made it possible to restore the distribution of farms and gardens of the mentioned period and to analyse the importance of viticulture and fruit farming in the 16th century. The maps represented show spatial patterns of vineyards, gardens, and main terroirs.
\end{abstract}

\section{Keywords}

Viticulture - fruit farming - terraced slopes - retrospective mapping • Samtskhe-Javakheti • Georgia

(C) University of Warsaw - Faculty of Geography and Regional Studies

\author{
Roman Maisuradze $\mathbb{B}^{1}$, \\ Tamar Khardziani $\mathbb{D}^{2}$ \\ Tea Eradze (i) 1 \\ IIvane Javakhishvili Tbilisi State University, \\ Faculty of Exact and Natural Sciences, \\ Department of Geography, Tbilisi, Georgia \\ e-mail: romani.maisuradze@tsu.ge \\ e-mail: tea.eradze@gmail.com \\ ${ }^{2}$ Ivane Javakhishvili Tbilisi State University, \\ Vakhushti Bagrationi Institute of Geography, \\ Department of Physical Geography, \\ Tbilisi,Georgia \\ e-mail: tamar.khardziani@tsu.ge \\ Received: 9 February 2019 \\ Accepted: 27 July 2019
}

\section{Introduction}

Landscape history is often part of landscape analysis, which has become of interest in land use planning due to the European Landscape Convention (Antonson 2018). In some parts of the world, vineyard landscapes play an important role in rural development. Having historical value (Foronda-Robles 2018), 'sixteen winegrowing regions around the world have been declared Heritage of Humanity cultural landscapes by UNESCO' (Petrillo et al. 2015). In many countries, winery landscapes have contributed a lot 'to the formation of local cultures' (Council of Europe 2000) and still 'play a cultural role in keeping up traditions and regional identities' (Myga-Piatek \& Rahmonov 2018). This can be said about Georgia where the history of winemaking and viticulture began 8,000 years ago (McGovern et al. 2017; Maghradze et al. 2019). One can find 525 autochthonous varieties of grapes here as well as the many populations of wild grapes Vitis vinifera ssp. Sylvestris (Maghradze et al. 2019). Wine culture has been developing continuously at least since the early Neolithic Period (McGovern et al. 2017) on the territory of Georgia. Taking the shorter historical period, viticulture 'landscape disappearance processes' (Myga-Piątek \& Rahmonov 2018) are observed in some parts of the country. In our study region, vineyards mostly disappeared in the Middle Ages due to historical and political factors. Although some physical features are still visible in the landscape, information is preserved as intangible cultural elements and written documents. The latter were the most important in our research.

As F. Braudel states in his famous conception, longue durée (1960), 'certain structures, in their long life, became the stable elements of an infinity of generations' (Braudel \& Wallerstein 2009). In some cases, viticulture landscape analysis shows that 'deep structures' (Braudel \& Wallerstein 2009) appear that are not easily removed from the culture even if they are physically destroyed, and are preserved in memory. For example, in Poland, vineyards have made a comeback in regions where the traces of former vineyards were corroborated by historical sources (MiętkiewskaBrynda \& Makowski 2018). New vineyards are being established from the successful restoration of those that existed in the Middle Ages (Myga-Piatek \& Rahmonov 2018). Currently, the reinterpretation of the agricultural landscape is evident in Georgia as well, where viticulture constitutes a significant element of the national identity. The wine sector is a strategic sector of the economy in the country. Many entrepreneurs are seeking ways to establish vineyards in terroirs with specific features and unique stories. This process leads to the reshaping of modern landscapes in some rural areas of Georgia. The remnants of the past determine the changes occurring in present-day landscapes. Apart from the physical features, the 16th century historic census document also represents firm evidence of the vineyard propagation in the study area. To see the long-term changes of the vineyard geography in the Samtskhe-Javakheti region, their historic propagation, and disturbance factors, we have applied a retrospective approach in the research.

Marc Bloch and Roger Dion broadly regarded knowledge of the past as indispensable to an understanding of the present landscape (Baker 1968). The retrospective approach, that had been advocated by Roger Dion in his study of French agrarian landscapes, considers that an understanding of the present landscape poses problems that can only be explained by a retrospective search for their origins (Gregory et al. 2011). Thus, the retrospective methodology means earlier sources throw 
light upon later times (Antonson 2018). Retrospective research starts with the oldest possible sources, e.g., maps, paintings, tithe records, or ethnographic interviews. The historical features are then compared with the current situation to identify changes (Antonson 2018).

In the research discussed below, the retrospective approach has been embedded in GIS mapping. Maps are spatial models wherein social reality is projected and partially explained; models are valid for all the temporalities and for all social categories (Braudel \& Wallerstein 2009). Geospatial methods are bound to become increasingly important for environmental history (Knowles 2005). One area where GIS has clear potential to shed new insights into geographical change, in ways that help to answer unresolved questions and ask entirely new questions, is to use the census and similar sources to explore change over time (Gregory \& Healey 2007). Scholars from many branches of historical study are turning to geospatial techniques to explore spatial relationships, to reconstruct past places and natural environments (Knowles 2005). Combining the retrospective approach with the historic geoinformation system (HGIS) technique turned out to be an effective instrument to revive viticulture and fruit farming patterns of 16th century Samtskhe-Javakheti, Georgia.

The Samtskhe-Javakheti region is no longer considered an important zone of viticulture and fruit farming. In the Middle Ages these were both highly developed in the region. In support of this fact, we can refer to folk tales, archeological materials and preserved ruined houses, old vineyard traces and different varieties of terraces: 'Oroko', 'Duqani', 'Lari', 'Dariji', 'Baqani' and 'Saque' (ed. Metreveli 2013). The 18th-century document by Vakhushti Bagrationi called Description of the Kingdom of Georgia is among the written sources proving the existence of the vineyards in the region. But the most important document we have included in our study is the Great Defter of Gurjistan Vilayet, composed by the Ottomans in the 16th century. In the 20th century, academician Sergi Jikia had collected the primary sources of the census, carried out by the Ottoman Empire in 1574, and published the Defter in Georgian in three parts. The first part contains original records in Turkish. The second part provides information in Georgian about the settlements, population, and taxes levied. The third part is also published in Georgian and contains descriptions of the locations of the settlements. The Defter was the first document for these territories, and was composed to levy the established taxes. Information about viticulture and fruit farming is given in great detail in the Defter as well (Svanidze 1971; Lomsadze 1975). It clearly states what quantity of money and natural taxes were levied on fruit trees and vineyards, though nothing is said about grape varieties and the species composition of fruit trees.

Thus, the work presents the results of the study and the zoning of viticulture and fruit farming, and their distribution, in the second half of the 16th century. The changes that took place in the ensuing centuries, as well as the current state, are considered

\section{The study area}

The territory under study includes the present administrative region of Samtskhe-Javakheti, which coincides with the historic provinces of Samtskhe and Javakheti (Figure 1).

This region is located in the Mtkvari river valley. From the north it is bordered by the Adjara-Trialeti ridge system. From the west it is bounded by the Arsiani ridge; from the east, by the Javakheti ridge. Javakheti and Erusheti volcanic massifs, the mountain basin - in the form of Akhaltsikhe (Samtskhe) structural basin - and Vardzia-Tmogvi volcanic canyons are located here. The landscape is mountainous; vertical zones are located here in the form of mountain deciduous forests, boreal, subalpine forest, high-mountain Alpine meadows, high-mountain sub-nival belts that create a diverse and interesting ecosystem mosaic (Maisuradze et al. 2018). The major soil types spread in the study area are the following: Mountain-Meadow (Leptosols), Brown Forest (Cambisols Eutric), Cinnamonic (Cambisols Cromic), Meadow Cinnamonic (Cambisols Chromic), Chernozems (Chernozems) (Urushadze \& Ghambashidze 2013). The lowest absolute minimum temperature in the region ranges between 29 and $41^{\circ} \mathrm{C}$. The absolute maximum temperature is $34-39^{\circ} \mathrm{C}$. The annual amplitude of temperature is as high as $24-25^{\circ} \mathrm{C}$, which refers to the continental character of climate in this region. The annual precipitation level on the territory of this region ranges between 400 and 1,400 $\mathrm{mm}$ (Lagidze 2015). The region unites six administrative municipalities: Borjomi, Akhaltsikhe, Adigeni, Aspindza, Akhalkalaki and Ninotsminda. The total population is 160,500 people (The National Statistics Office of Georgia \& the United Nations Population Fund 2018). Three urban, seven semi-urban and predominantly rural settlements are represented in the region.

\section{Materials and methods}

The following materials are used in the work:

1. Parts II and III of the Great Defter of Gurjistan Vilayet; in the second part the administrative units entering the Vilayet, classified as 'Liva' ('Sanjak'), and the districts (Nahias) entering it are given. The local population is registered for the settlements; also, the quantity of levied taxes is given both in money and natural forms. The fruit and wine taxes are given, which emphasize the availability and development of these sectors in the region (Jikia 1941; Jikia 1958);

2. The map of the Gurjistan Vilayet composed in 1953, at a scale of 1:350 000 (Aslanikashvili 1953);

3. Topographic maps (at a scale of 1:50 000, 1:25 000);

4. Satellite images;

5. The maps of the viticulture and fruit farming zones of Georgia, where the modern distribution zone of vineyards is shown (Aslanikashvili et al. 1964; Kharbedia 2006);

6. Results of agricultural censuses conducted at the beginning of the 20th century and in the most recent period (National Statistics Office of Georgia 2016; Central Division of Statistics 1925).

The research included several stages. The initial stage included the creation of the administrative arrangement map of the Gurjistan Vilayet in digital format and the identification of the geographical objects and borders of administrative units, as described in the Defter. These were followed by the identification of the settlements using the topographic maps (1:25 000) and aerial images (ArcGIS Basemap) and the creation of the relevant attribute tables, which included information about the tax amount levied in the form of wine and fruit. The amount of the taxes, which was equal to one-fifth of the total harvest (Svanidze 1971), gave us the total quantitative indicators about the production of wine and fruit, which afterward was summed up within the borders of Nahias and Livas. The calculations made showed the quantitative indicators on available fruit and wine for separate villages and within the borders of the administrative unit of that time.

During the field research, we studied the spatial distribution of vineyards, gardens, and other agricultural plots, where the traces of the historical agricultural landscapes are preserved even today in the form of separate vineyards and fruit trees, old terraces and so-called 'Lari' in the vicinity of ruined houses.

The large-scale topographical maps (1:25 000) and aerial images were used to identify the lands suitable for agriculture, where crop farming occurred, and perennial plantings were cultivated, etc. Afterward, the thematic maps were compiled, using the GIS database, that gave us the pattern reflecting the distribution of vineyards and orchards for each populated place. 


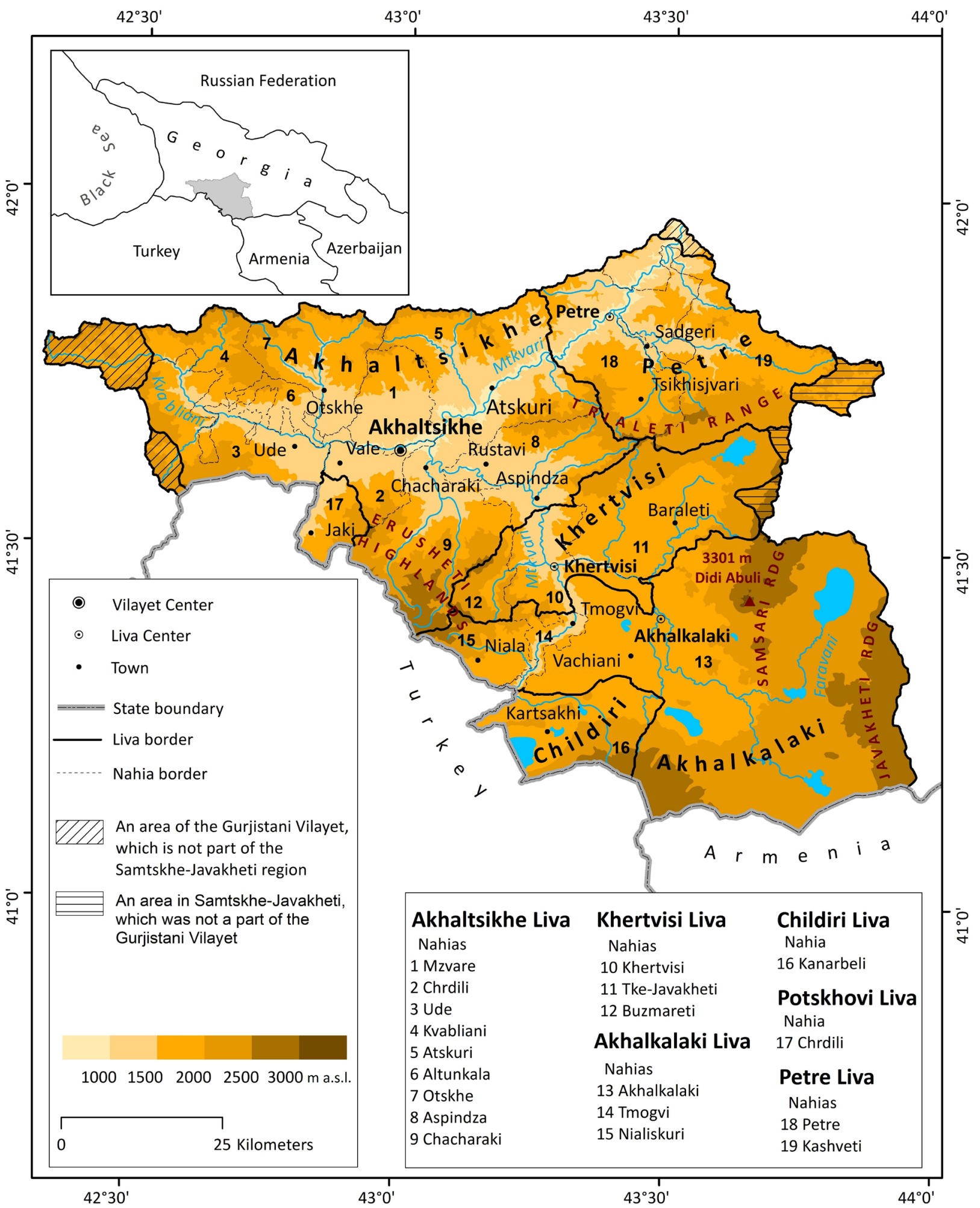

Figure 1. Location of the study area. An administrative division of Samtskhe-Javakheti in the second half of the 16th century. Source: Author's map based on information from the Great Defter of Gurjistan Vilayet, part II, part III (Jikia 1941; Jikia 1958) 


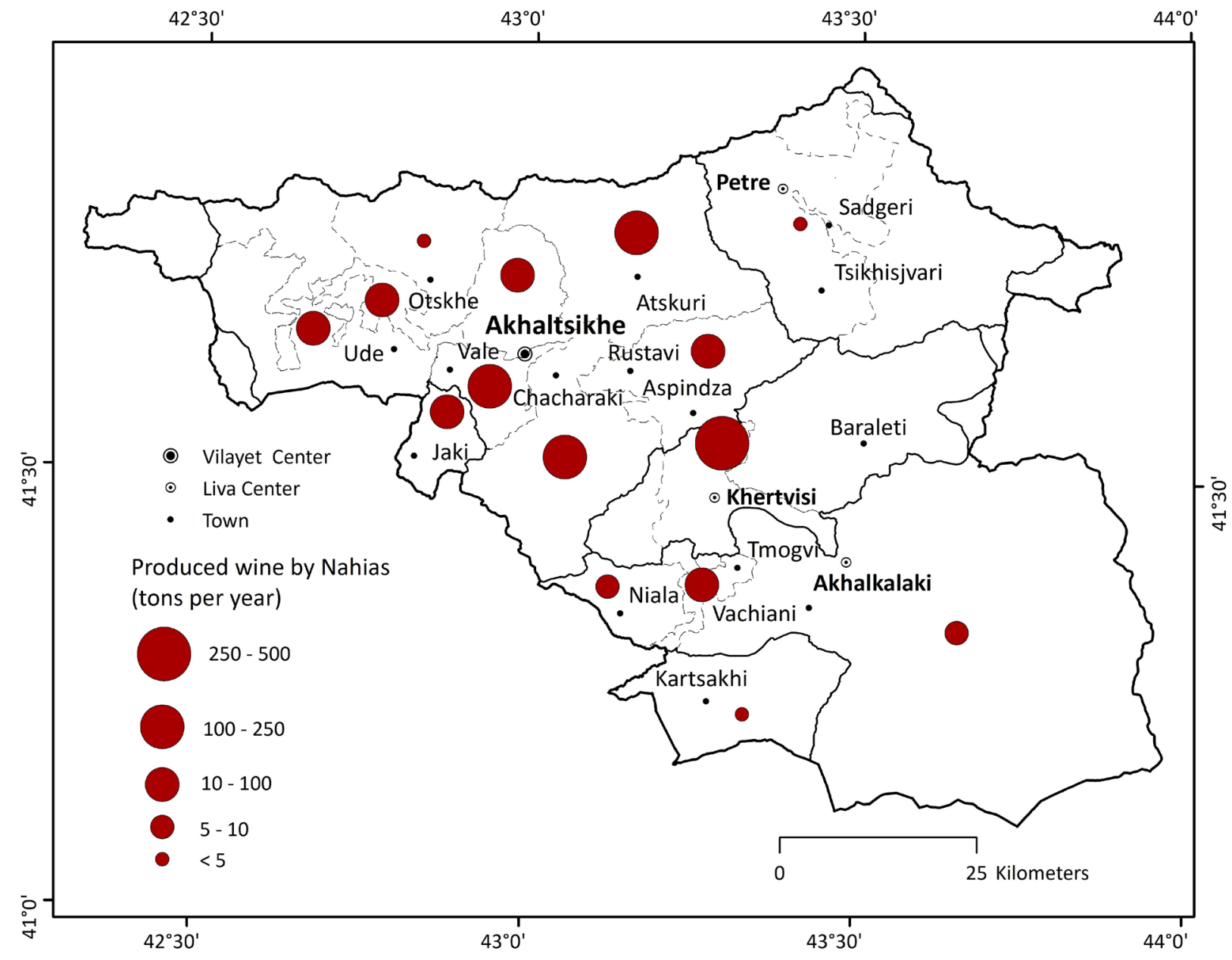

Figure 2. Annually produced wine by 'Nahias'.

Source: Author's map based on information from the Great Defter of Gurjistan Vilayet, part II (Jikia 1941).

Almost half of the millennium had passed after the second part of the 16th century. The time interval is large and during this period the viticulture and fruit farming sectors experienced lots of changes. On the basis of comparative analysis of available materials, we tried to establish to what extent the present-day zone coincides with the pattern of the surveyed period. We also analyzed the determining factors regarding the disappearance of viticulture in the region.

\section{Results}

Based on the research it was figured out that 120 out of 712 villages had the levied tax on the orchards, with 135 settlements on the wine. As a consequence, vineyards were located and wine was made in these villages (Figure 3 ). It should also be noted that the villages, which were already devastated at that time, are described in the Defter. These villages were obliged to pay the unified monetary tax for the population that might have settled in the empty villages. Nothing is said in the source that could point to the availability of fruit trees or vineyards in these villages, though their location, landscape, climate and soil conditions make us think that viticulture and fruit farming would have been developed in these settlements prior to their devastation.

The maximum quantity of wine laid on as a tribute was registered for Atskuri and Khertvisi 'Nahias' (Figure 2). They are followed by Mzvare, Chrdili, Aspindza and Chacharaki 'Nahias', which were united into Akhaltsikhe 'Liva'. In Kashveti, TkeJavakheti, Buzmareti and Kvabliani 'Nahias' the vine plantings were either not registered or they were very insignificant amounts. Kanarbeli, Akhalkalaki, Otskhe and Petre 'Nahias', where one can barely find the plantings in single settlements, were characterized by very small indicators as well (Table 1).

Almost the same, though a slightly different pattern is registered regarding fruit plantings (Figure 6), where the highest indicators were registered for Mzvare, Atskuri and Chacharaki 'Nahias' (Figure 4). Chrdili (Akhaltsikhe 'Liva'), Aspindza and Khertvisi 'Nahias' fall behind them and, similar to vineyards, fruit plantings almost didn't exist in Kvabliani, Kashveti, TkeJavakheti and Buzmareti 'Nahias'. However, it was found in very small quantities in Akhalkalaki 'Nahia', which was predetermined by climatic factors; climatic factors must be a factor in case of Kanarbeli, where a better state seems to be registered, but presumably this indicator is increased at the expense of Oloda and Mrakvali villages that were located near the Mtkvari floodplain and could be found in the viticulture and fruit farming zones of this place.

During viticulture zonation, several terroirs (Figure 3 ) were identified, which supplied both the entire region and districts located beyond it with wine and grape products (sherbet, raisins, Churchkhela, etc.). Such terroirs are: 1. Dviri-Atskuri terroir in the Mtkvari river valley, Dviri-Atskuri-Sakuneti-Tsnisi band; 2. Ude- 
Table 1. Annual production of wine and fruit crops in administrative units entering into the Gurjistan Vilayet in the second half of the 16th century

\begin{tabular}{|c|c|c|c|c|c|c|c|}
\hline $\begin{array}{c}\text { Administrative } \\
\text { units (Liva and } \\
\text { Nahia) }\end{array}$ & $\begin{array}{l}\text { Agricultural } \\
\text { crops }\end{array}$ & $\begin{array}{c}\text { Number of } \\
\text { settlements } \\
\text { with vineyards } \\
\text { and/or gardens }\end{array}$ & $\begin{array}{c}\text { Total } \\
\text { number } \\
\text { (tons) }\end{array}$ & $\begin{array}{c}\text { Administrative } \\
\text { units (Liva and } \\
\text { Nahia) }\end{array}$ & $\begin{array}{l}\text { Agricultural } \\
\text { crops }\end{array}$ & $\begin{array}{c}\text { Number of } \\
\text { settlements } \\
\text { with vineyards } \\
\text { and/or gardens }\end{array}$ & $\begin{array}{c}\text { Total } \\
\text { number } \\
\text { (tons) }\end{array}$ \\
\hline \multicolumn{4}{|c|}{ Akhaltsikhe Liva } & \multicolumn{4}{|c|}{ Akshehiri (Akhalkalaki) Liva } \\
\hline \multirow{2}{*}{ Mzvare } & Vine & 10 & 80 & \multirow{2}{*}{$\begin{array}{c}\text { Akshehiri } \\
\text { (Akhalkalaki) }\end{array}$} & Vine & 2 & 9.6 \\
\hline & Fruit & 11 & 34.02 & & Fruit & 2 & 0.875 \\
\hline \multirow{2}{*}{ Chrdili } & Vine & 11 & 107.2 & \multirow{2}{*}{ Tmogvi } & Vine & 8 & 63.36 \\
\hline & Fruit & 14 & 14.602 & & Fruit & 5 & 5.215 \\
\hline \multirow{2}{*}{ Ude } & Vine & 9 & 28.8 & \multirow{2}{*}{ Nialiskuri } & Vine & 3 & 9.6 \\
\hline & Fruit & 9 & 9.205 & & Fruit & 2 & 1.253 \\
\hline \multirow{2}{*}{ Kvabliani } & Vine & 0 & 0 & \multirow{2}{*}{ Total in Liva } & Vine & 13 & 82.56 \\
\hline & Fruit & 0 & 0 & & Fruit & 9 & 7.343 \\
\hline \multirow{2}{*}{ Otskhe } & Vine & 1 & 3.2 & \multicolumn{4}{|c|}{ Childiri Liva } \\
\hline & Fruit & 2 & 2.1 & \multirow[b]{2}{*}{ Kanarbeli } & Vine & 1 & 3.2 \\
\hline \multirow{2}{*}{ Atskuri } & Vine & 24 & 242.56 & & Fruit & 1 & 2.1 \\
\hline & Fruit & 20 & 27.51 & \multirow[b]{2}{*}{ Total in Liva } & Vine & 1 & 3.2 \\
\hline \multirow{2}{*}{$\begin{array}{c}\text { Altunkala } \\
\text { (Okrostsikhe) }\end{array}$} & Vine & 4 & 20.16 & & Fruit & 1 & 2.1 \\
\hline & Fruit & 2 & 1.75 & \multicolumn{4}{|c|}{ Potskhovi Liva } \\
\hline \multirow{2}{*}{ Aspindza } & Vine & 20 & 75.52 & \multirow[b]{2}{*}{ Chrdili } & Vine & 4 & 11.2 \\
\hline & Fruit & 18 & 16.555 & & Fruit & 4 & 3.85 \\
\hline \multirow{2}{*}{ Chacharaki } & Vine & 18 & 142.72 & \multirow{3}{*}{ Total in Liva } & Vine & 4 & 11.2 \\
\hline & Fruit & 15 & 25.55 & & Fruit & 4 & 385 \\
\hline \multirow{3}{*}{$\begin{array}{l}\text { Total within the } \\
\text { Liva }\end{array}$} & Vine & 97 & 700.16 & & Fruit & & 0.00 \\
\hline & & & & \multicolumn{4}{|c|}{ Petre Liva } \\
\hline & Fruit & 91 & 131.292 & & Vine & 2 & 3.2 \\
\hline & Khertvis & i Liva & & Petre & Fruit & 2 & 1.575 \\
\hline Khorturi & Vine & 18 & 361.6 & & Vine & 0 & 0 \\
\hline 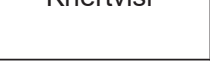 & Fruit & 13 & 14.735 & Kashvetı & Fruit & 0 & 0 \\
\hline Tke-Javakleti & Vine & 0 & 0 & & Vine & 2 & 3.2 \\
\hline Javakheti) & Fruit & 0 & 0 & Total in LIVa & Fruit & 2 & 1.575 \\
\hline Buzmareti & Vine & 0 & 0 & $\begin{array}{l}\text { Total number } \\
\text { within the }\end{array}$ & Vine & 135 & 1161.92 \\
\hline & Fruit & 0 & 0 & „Gurjistan & & & \\
\hline & Vine & 18 & 361.6 & $\begin{array}{l}\text { Vilayet" (within } \\
\text { the territory }\end{array}$ & Fruit & 119 & 160.895 \\
\hline Iotal In Liva & Fruit & 13 & 14.735 & $\begin{array}{c}\text { of modern } \\
\text { Georgia) }\end{array}$ & & & \\
\hline
\end{tabular}

Source: Table elaborated by the authors based on materials from the Great Defter of Gurjistan Vilayet, part II (Jikia 1941) 

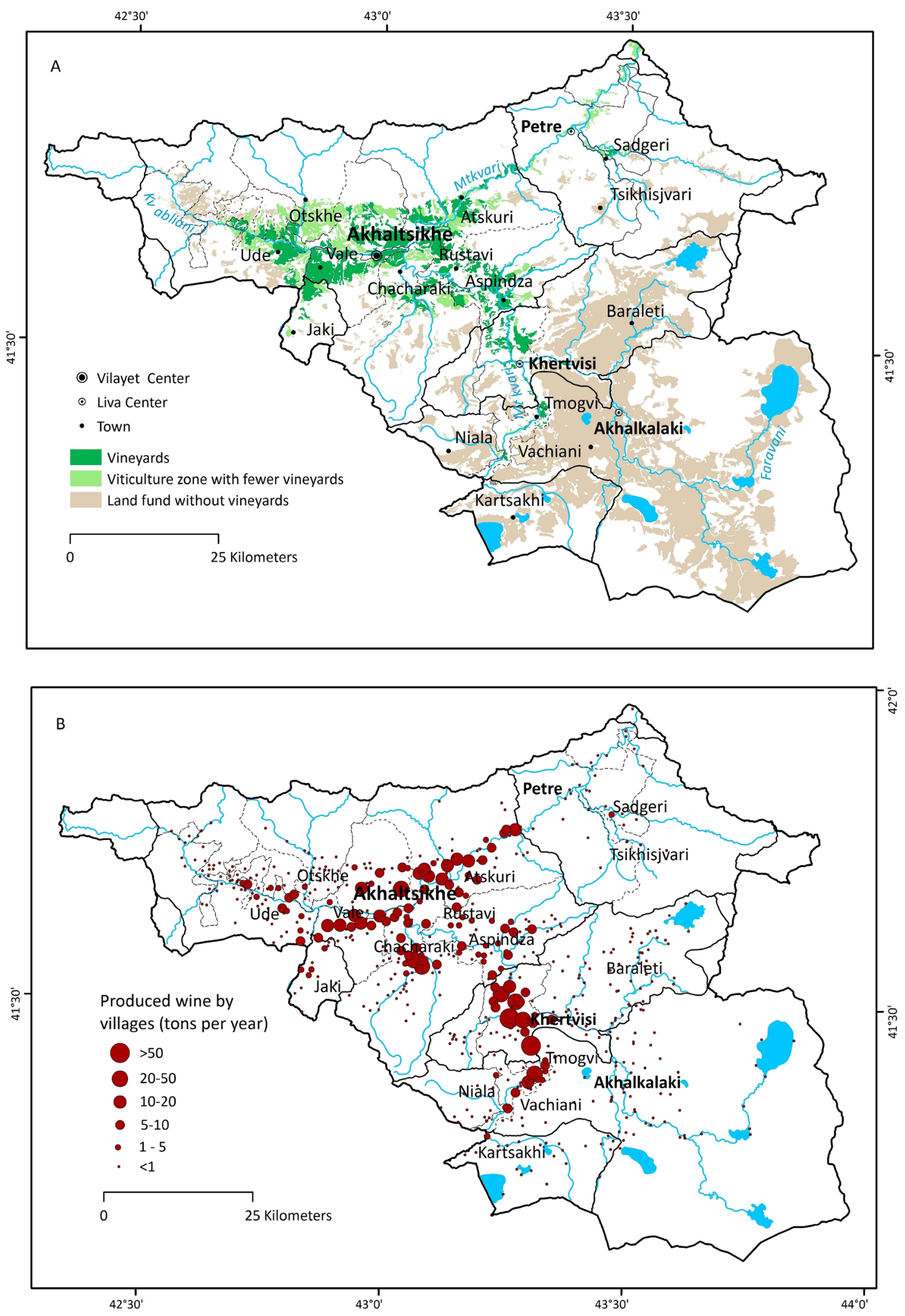

Figure 3. A. Vineyards of Samtskhe-Javakheti in the second half of the 16th century; B. Wine production in the study area in the second half of the 16th century.

Source: Author's maps based on information from the Great Defter of Gurjistan Vilayet, part II, part III (Jikia 1941; Jikia 1958) 


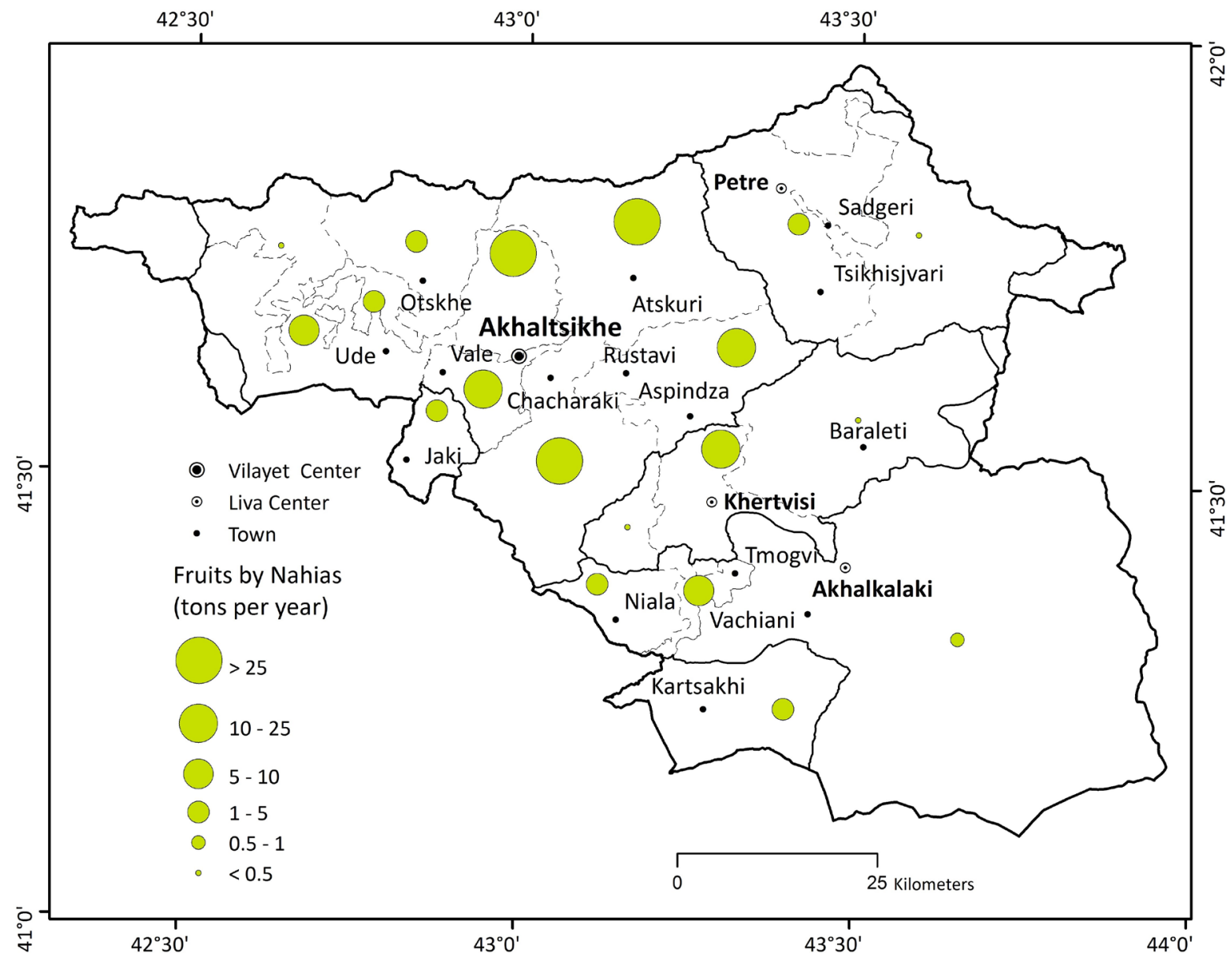

Figure 4. Annual quantity of fruit crops by 'Nahias' in the second half of the 16th century. Source: Author's map based on information from the Great Defter of Gurjistan Vilayet, part II (Jikia 1941)

Maidani-Belnara band, located in the Kvabliani and Odzrkhe river valleys; 3 . Potskhovi-Vale-Ghreli terroir - terraces without walls developed on the wavy topography; 4 . Uraveli gorge, terroir at the Tskordza-Anda-Fugha-Uraveli section; 5. Rustavi-Aspindza terroir in the Mtkvari river valley on the river alluvial fans and floodplains, at the Rustavi-Akhalsheni-Aspindza-Erkota section; 6. Khizabavra-Nijgori-Khertvisi-Oloda terroir, which includes floodplains and artificial terraces made on the slopes.

It can be said that the sixth terroir is unique to the study region and to all of Georgia. For this terroir the vineyards were spread at a high hypsometric mark, up to 1,550-1,600 $\mathrm{m}$. Vineyards disappeared a long time ago from this terroir. In recent years, at the Nijgori-Saro-Khizabavra villages section, the restoration of terraces for wine growing has been started (Figure 7). In 2017, during our expedition to Javakheti villages (Khulgulo, Kartikami) we came across the growing vines wrapped around single trees in the yards, which are spread up to $1,700-1,800 \mathrm{~m}$ above sea level.

Fruit plantings partly coincide with the vine distribution zone, though their concentration zones are not particularly featured. We can emphasize Atskuri, the Akhaltsikhe structural basin, Uraveli gorge and Aspindza-Khizabavra-Nijgori-Mirashkhani sub-zones, where fruit plantings are mainly concentrated (Figure 5).

Nowadays, the vine plantings occupy six hectares only, while orchards occupy 664 hectares (National Statistics Office of Georgia 2016). If we compare them with the last century census data, we will clearly see a big difference in vine plantings. Vineyard areas have reduced, while the downward trend among fruit plantings is less obvious (Table 2).

If we judge by the area of vine plantings and wine quantity, we will see that the downward trend is clearly evident. Two periods, related to the active socio-political changes, had an evident impact on viticulture: 1 . the last period of the 16th century and 2 . the beginning of the 20th century. A decrease in vineyard area was obvious; such a trend is observed both prior to the Soviet period - and is related to the extension of Islamic cultural influence, and during the Ottoman period. As for the changes taking place in the first half of the 20th century, they are associated with Soviet agricultural reforms and the state-planned economy, and were expressed in regional 'specialization', and assisted in the formation of monoculture. As for fruit plantings we can see that there is a substantial difference between the 16 th and 20th centuries. There were a lot more plantings referred to at the beginning of the Soviet period than were described in the Defter. On the one hand, it can be explained by the fact that during the Ottoman ruling period the scale of fruit farming may have increased at the expense of a reduction in viticulture zones; on the other hand, the reason may be that the population of the region under study had increased 5 to 6 times by 1926 compared to that described in the Defter. 

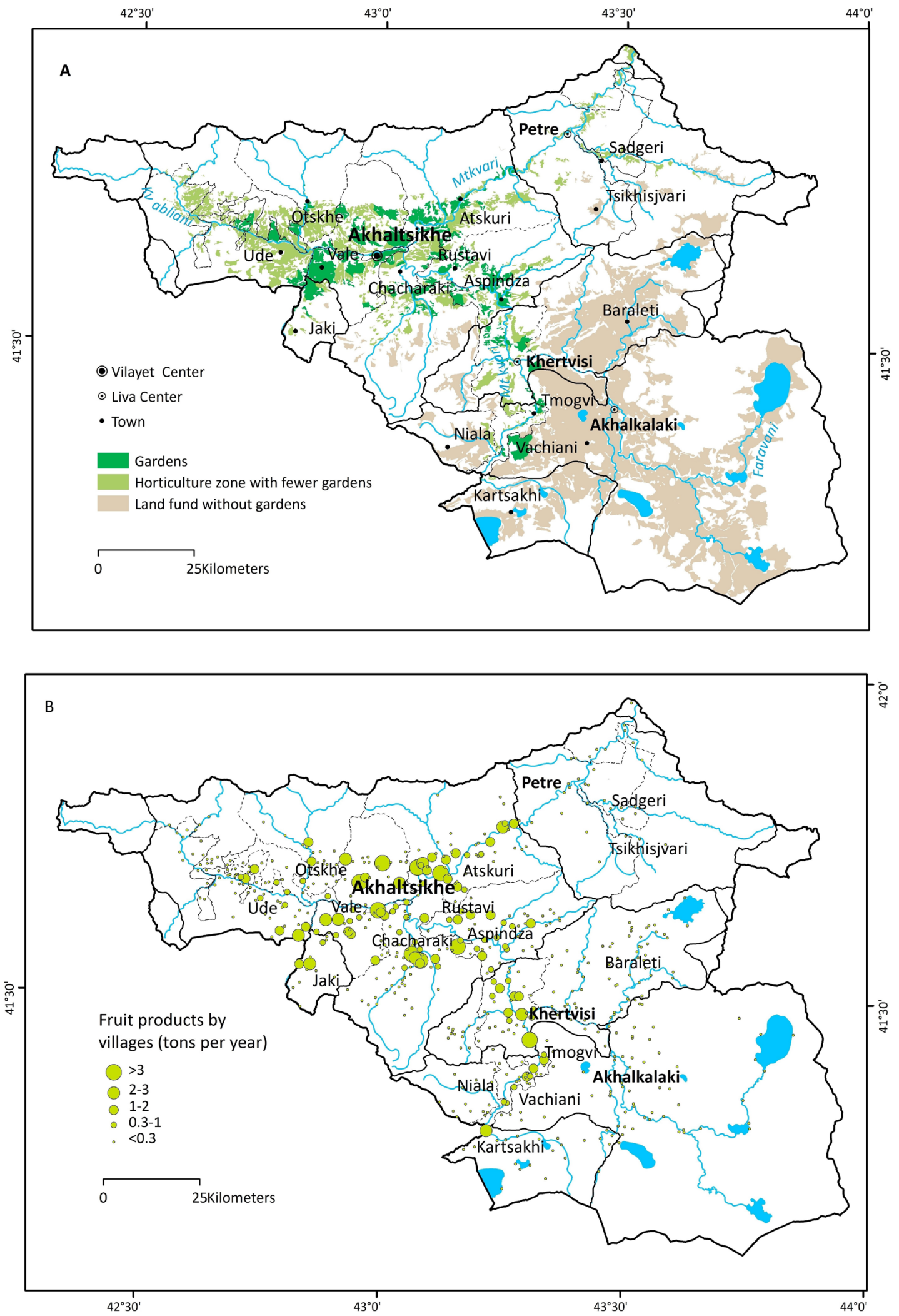

Figure 5. A. Gardens of Samtskhe-Javakheti in the second half of the 16th century; B. Fruit production in the study area in the second half of the 16 th century.

Source: Author's maps based on information from the Great Defter of Gurjistan Vilayet, part II, part III (Jikia 1941; Jikia 1958) 
Table 2. Vine and fruit plantings in the study area in 1923

\begin{tabular}{|c|c|c|c|c|c|c|c|}
\hline \multirow[t]{2}{*}{$\begin{array}{c}\text { Mazra (an } \\
\text { administrative unit) }\end{array}$} & \multirow[t]{2}{*}{ No. } & \multirow[t]{2}{*}{ Community } & \multicolumn{5}{|c|}{ Agriculture } \\
\hline & & & Vineyards (ha) & Grapes (tons) & Vine (tons) & $\begin{array}{l}\text { Fruit Gardens } \\
\text { (ha) }\end{array}$ & Fruit (tons) \\
\hline \multirow{10}{*}{ Akhalkalaki } & 1 & Alastani & 0 & 0 & 0 & 2.8 & 42.5 \\
\hline & 2 & Baraleti & 0 & 0 & 0 & 0 & 0 \\
\hline & 3 & Gorelovo & 0 & 0 & 0 & 0 & 0 \\
\hline & 4 & Diltska & 0 & 0 & 0 & 5.8 & 86.66 \\
\hline & 5 & Eshtio & 0 & 0 & 0 & 0 & 0 \\
\hline & 6 & Kondura & 0 & 0 & 0 & 0 & 0 \\
\hline & 7 & Kulikami & 0 & 0 & 0 & 0 & 0 \\
\hline & 8 & Okami & 0 & 0 & 0 & 20.492 & 307.38 \\
\hline & 9 & Satkha & 0 & 0 & 0 & 0 & 0 \\
\hline & 10 & Khertvisi & 1.1 & 3.27 & 1.9 & 95.16 & 1427.36 \\
\hline & & All & 1.09 & 3.27 & 1.9 & 124.26 & 1863.9 \\
\hline \multirow{11}{*}{ Akhaltsikhe } & 1 & Adigeni & 0 & 0 & 0 & 32.9 & 493.8 \\
\hline & 2 & Atskuri & 0.9 & 2.6 & 1.57 & 59.9 & 897.6 \\
\hline & 3 & Vale & 0 & 0 & 0 & 81.532 & 1222.98 \\
\hline & 4 & Varkhani & 0 & 0 & 0 & 51.9 & 778.26 \\
\hline & 5 & Idumala & 0 & 0 & 0 & 36.08 & 541.2 \\
\hline & 6 & Klde & 0 & 0 & 0 & 63.55 & 953.2 \\
\hline & 7 & Lepisi & 0.44 & 1.3 & 0.8 & 48.7 & 730.9 \\
\hline & 8 & Ude & 0.11 & 0.33 & 0.2 & 180.9 & 2714.1 \\
\hline & 9 & Uraveli & 11.9 & 35.7 & 21.4 & 66.9 & 1003.9 \\
\hline & 10 & Akhaltsikhe city & 0 & 0 & 0 & 13.6 & 204.4 \\
\hline & & All & 13.3 & 39.9 & 23.94 & 636.01 & 9540.2 \\
\hline \multirow{8}{*}{$\begin{array}{l}\text { Gori (communities } \\
\text { within the 'Gurjistan } \\
\text { Villaiet' territory) }\end{array}$} & 4 & Akhaldaba & 6.9 & 20.6 & 12.34 & 1.86 & 27.8 \\
\hline & 7 & Bakuriani & 0 & 0 & 0 & 0 & 0 \\
\hline & 8 & Borjomi & 0.3 & 0.98 & 0.6 & 5 & 75.2 \\
\hline & 11 & Gujareti & 0 & 0 & 0 & 0 & 0 \\
\hline & 12 & Dviri & 0.66 & 1.96 & 1.2 & 1.1 & 16.35 \\
\hline & 32 & Kvishkheti & 24.5 & 73.6 & 44.1 & 9 & 135.7 \\
\hline & 36 & Tsagveri & 0 & 0 & 0 & 0 & 0 \\
\hline & & All & 32.4 & 97.1 & 58.3 & 17 & 255 \\
\hline Total & & & 46.8 & 140.6 & 84.2 & 777.3 & 11659.2 \\
\hline
\end{tabular}

Source: Table elaborated by the authors based on materials from the Agricultural Census of Georgia in 1923, part I, community sums (Central Division of Statistics 1925) 


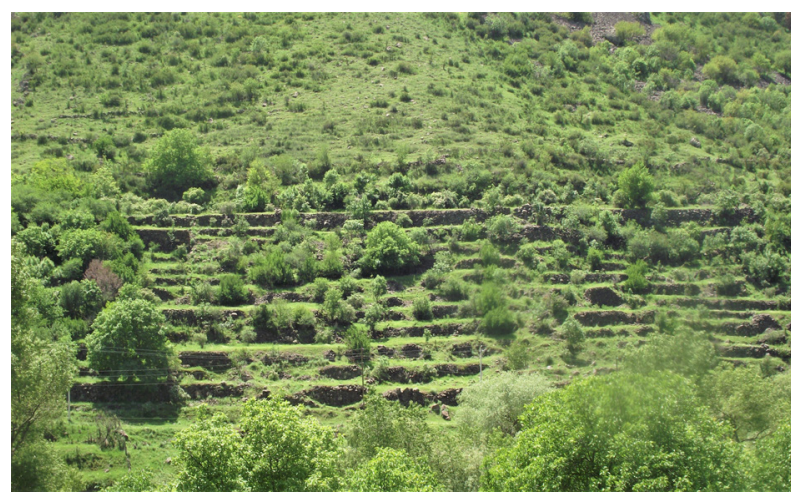

Figure 6. Historical viticulture zone and artificial terraces at the Toloshi-Khertvisi section. Source: Photographed by Tamar Khardziani, 2018

\section{Conclusions}

1. According to the tax content and amounts, described in the Great Defter of Gurjistan Vilayet, more than one-fifth of the settlements owned the vineyards, which indicates that the cultivation of wine was widespread in Samtskhe-Javakheti in the 16 th century.

2. The identification of the census data locations made explicit the spatial patterns of viticulture and fruit farming of the study region in the second half of the 16th century. The wine grape and other fruits spatially overlapped in most cases. Some vineyards were located in unfavorable climate conditions, needing special care.

3. According to the agricultural census, viticulture had disappeared in most areas of the study region at the beginning of the 20th century, but fruit farming was still preserved. The disappearance of viticulture was religiously provoked due to the expansion of the Ottoman Empire and the spread of Islam.

4. Viticulture development in Samtskhe-Javakheti was neglected in Soviet agricultural policies, which were oriented towards high yield. The small terroirs located in harsh climatic conditions did not contribute to the production of wine grapes. Thus, the disappearance of historical vineyard landscapes continued during Soviet times as well.

5. Rethinking and reinterpretation of the historical agricultural landscapes contribute to the formation of small-scale terroirs

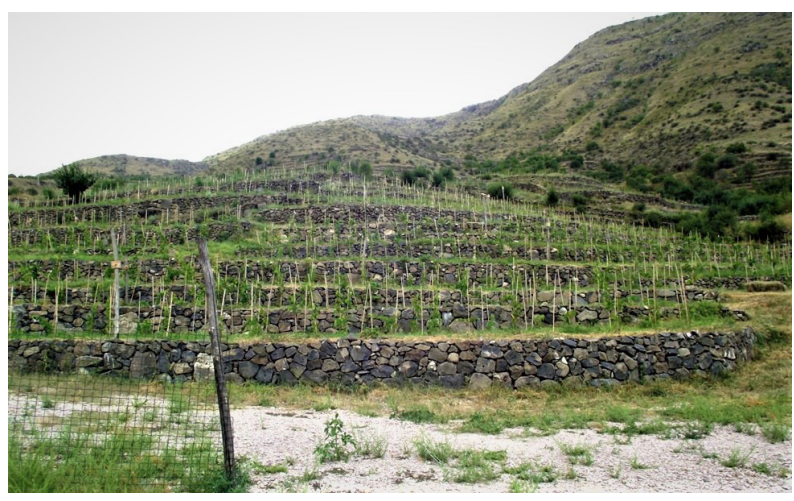

Figure 7. Khizabavra restored terraces.

Source: Photographed by Roman Maisuradze, 2017

in some parts of modern Georgia. The newly restored terraced vineyards are already visible in the landscapes of Samtskhe-Javakheti. Wine culture constitutes a stable element of the Georgian identity, and is reshaping the rural landscape in our times as well. There are examples of the restoration of historical viticulture landscapes even in regions where they disappeared a long time ago. Our study revealed the historical winery zone, Khizabavra-NijgoriKhertvisi-Oloda terroir, where one can still find physical remnants of the old vineyard landscapes, as well as newly established ones. The historical document studied in the research proves the existence of vineyards in this specific terroir, which is shown on the maps composed with a retrospective approach.

\section{Acknowledgments}

This research was supported by the Shota Rustaveli National Science Foundation of Georgia (SRNSFG) [grant number YS2016-44].

\section{ORCID}

Roman Maisuradze (1D https://orcid.org/0000-0001-9583-7142

Tamar Khardziani (1) https://orcid.org/0000-0002-5292-9538

Tea Eradze (1D) https://orcid.org/0000-0002-3312-059X

\section{References}

Antonson, H 2018, 'Revisiting the "Reading Landscape Backwards" approach: advantages, disadvantages, and use of the retrogressive method', Rural Landscapes: Society, Environment, History, vol. 5 (1), no. 4, pp. 1-15

Aslanikashvili, AT 1953, Gurjistanis vilaietis ruka [Map of the Gurjistan Vilayet], Tbilisi.

Aslanikashvili, AT, Gvelesiani, GG \& Zautashvili, EK 1964, Mevenaxeoba [Viticulture] in Atlas of the Soviet Republic of Georgia, Tbilisi-Moscow.

Baker, AR 1968, 'A note on the retrogressive and retrospective approaches in historical geography' ('Bemerkungen zu retrogressiven und retrospektiven Methoden in der Historischen Geographie'), Erdkunde, pp.244-245.

Braudel, F \& Wallerstein, I 2009, 'History and the social sciences: the longue durée, Review (Fernand Braudel Center), pp.171-203.

Central Division of Statistics 1925, Saqartvelos 1923 tslis sasoflosameurneo agtsera: satemo jamebi [Agricultural Census of Georgia in 1923: community sums], part I, Tbilisi.
Europe, CO 2000, European landscape convention convention.

Foronda-Robles, C 2018, 'The territorial redefinition of the Vineyard Landscape in the sherry wine region (Spain)', Miscellanea Geographica, vol. 22, no. 2, pp. 95-101.

Gregory, D, Johnston, R, Pratt, G, Watts, M \& Whatmore, S (eds.) 2009, The dictionary of human geography, John Wiley \& Sons.

Gregory, IN \& Healey, RG 2007, 'Historical GIS: structuring, mapping and analyzing geographies of the past', Progress in human geography, vol. 31, no. 5, pp.638-653.

Jikia, S 1941, Gurjistanis vilaietis didi davtari [Great Defter of Gurjistan Vilayet], part II, Publishing House of the Georgian Academy of Sciences of Soviet Republic of Georgia, Tbilisi.

Jikia, S 1958, Gurjistanis vilaietis didi davtari [Great Defter of Gurjistan Vilayet], part III, Publishing House of the Georgian Academy of Sciences of Soviet Republic of Georgia, Tbilisi]. Kharbedia, M 2006, Georgian Wine Guide, Tbilisi.

Knowles, AK 2005, 'Emerging trends in historical GIS', Historical Geography, vol. 33, pp.7-13. 
Lagidze, L 2015, 'The role of landscape in climate formation (Samtskhe Javakheti region, Georgia)', 4th International Conference on Earth Science \& Climate Change, Alicante, Spain.

Lomsadze, Sh 1975, Samtsxe-Javaxeti: XVIII saukunis shua tslebidan XIX saukunis shua tslebamde [SamtskheJavakheti: from the middle of XVIII to middle of XIX centuries], Metsniereba, Tbilisi.

Maghradze, D, Aslanishvili, A, Mdinaradze, I, Tkemaladze, D, Mekhuzla, L, Lordkipanidze, D, Jalabadze, M, Kvavadze, E, Rusishvili, N, McGovern, P \& This, P 2019, 'Progress for research of grape and wine culture in Georgia, the South Caucasus', In BIO Web of Conferences, vol. 12, pp. 1-10.

Maisuradze, R, Elizbarashvili, M, Khardziani, T \& Tatishvili, M 2018, 'Landscapes of Samtskhe-javakheti region, transformation degree and forms', Surveying Geology \& Mining Ecology Management (SGEM), vol. 18, no. 5.1, pp. 487-494.

McGovern, P, Jalabadze, M, Batiuk, S, Callahan, MP, Smith, KE, Hall, GR, Kvavadze, E, Maghradze, D, Rusishvili, N, Bouby, L \& Failla, O, 2017, 'Early Neolithic wine of Georgia in the South Caucasus', Proceedings of the National Academy of Sciences, vol. 114 no. 48, pp. E10309-E10318.

Metreveli, R (ed.) 2013, Qartuli materialuri kulturis etnografiuli leqsikoni [Ethnographic dictionary of the Georgian material culture], Meridiani, Tbilisi.

Miętkiewska-Brynda, J \& Makowski, J 2018, 'Viticultural landscapes in transition: permanence and change', Miscellanea Geographica, vol. 22, no. 2, pp.63-68.

Myga-Piątek, U \& Rahmonov, O 2018, 'Winery regions as the oldest cultural landscapes: remnants, signs, and metamorphoses', Miscellanea Geographica, vol. 22, no. 2, pp.69-80.

National Statistics Office of Georgia 2016, Census of Agriculture 2014. Available from: <http://census.ge/files/results/ agriculture/>. [3 December 2018].

Petrillo, PL, Di Bella, O \& Di Palo, N 2015, 'The UNESCO World Heritage Convention and the Enhancement of Rural VineGrowing Landscapes', Cultural Heritage and Value Creation, Springer International Publishing, pp. 127-169.

Svanidze, M 1971, Saqartvelo-osmaletis urtiertobis istoriidan XVI-XVII saukuneebshi [From the history of GeorgianOttoman relations in XVI-XVII centuries], Metsniereba, Tbilisi.

The National Statistics Office of Georgia \& the United Nations Population Fund 2018, Population Dynamics in Georgia - An Overview Based on the 2014 General Population Census Data. Available from: <https://georgia.unfpa.org/en/ publications/population-dynamics-georgia-overview-based2014-general-population-census-data>. [3 December 2018].

Urushadze, TF \& Ghambashidze, G 2013, 'Soils of Georgia', Soil Resources of Mediterranean and Caucasus Countries, pp. 77-96. 